\title{
TRANSFER OF COMPANY'S SEAT - AN UNFOLDING STORY IN EUROPE
}

\author{
Carsten Frost*
}

\begin{abstract}
The harmonisation of company law has long been a goal of the European Union. Questions concerning the freedom of establishment have always been both a central and controversial area of European law. The European Court of Justice has decided in favour of the freedom of establishment of EU companies establishing themselves in other Member States in several cases since Centros in 1999, resulting in a discernible and consistent line of authority. The Court has made clear that Member States have to allow companies that have been incorporated in other Member States to freely enter their territory, according to the rules under which they have been formed in their state of origin.
\end{abstract}

But the decisions have left other important questions open to doubt. The purpose of this article is to examine the consequences of these judgments, not only for European company law, but for related legal areas as well. The paper addresses this issue by giving a short overview on the freedom of establishment under the Treaty Establishing the European Community and on the existing European theories about the transfer of a company's seat. It then analyses the European Court of Justice cases and their implications. The article argues that the pressure on national legislators that arises from the judgments helps to keep European company law attractive to investors. It concludes that an increased mobility of companies within Europe is necessary if Europe is to remain competitive on an international level, even if the price of this is the abolition of some traditional domestic legal principles.

\section{INTRODUCTION}

Company law reforms are on the agenda of many countries, especially within the European Union (EU). Harmonisation of corporate law has been on the European agenda for at least 35 years, mandated by article 220 of the Treaty Establishing the European Community (the EC Treaty) of 25 March 1957. ${ }^{1}$ Some progress has been made, but it has been slow. For instance the Societas

* Submitted as part of the LLM programme at Victoria University of Wellington.

1 Treaty Establishing the European Community (Consolidated text) [2002] OJ C325, art 220 requires Member States to enter into negotiations regarding, inter alia, the possibility of mergers between companies governed by the laws of different countries, and the mutual recognition of companies. 
Europaea (SE) - the European company - has been available since autumn 2004 after it was first proposed in $1970 .{ }^{2}$ The main driving forces behind efforts to reform and harmonise existing corporate laws are similar in every nation: the pressures of globalisation and competition, the growth of the shareholder population, and the emergence of new technologies and industries. ${ }^{3}$ All of these factors require companies to become increasingly flexible, not only economically and strategically, but also geographically, if they want to be competitive. However, the approaches to deal with these new challenges differ considerably.

The transfer of a company's seat has been the subject of controversy in European company law for decades. Only very few Member States' company laws provide for companies registered in their territories to transfer their registered office to another Member State while remaining the same legal person. For example, this is possible under Italian and Portuguese laws, as long as the operation also is possible under the law of the future home state. French law allows a transfer subject to international agreements that do not exist, while German law excludes the possibility outright. The fundamental gap in European company law systems is based partly on the tension between the incorporation theory on the one hand and the real seat theory on the other hand. As a consequence, companies were prevented from enjoying the same freedom of establishment as natural persons.

This article analyses the scope of articles 43 and 48 of the Treaty Establishing the European Community concerning the freedom of establishment of companies and then looks at the basic differences between the two criteria used to determine a company's parentage. The analysis is based on the essential case law from the European Court of Justice (ECJ) regarding the freedom of establishment for companies and encompasses consequences for company law as well as related legal areas. Attempts to harmonise company law on a legislative level, such as the European Company Regulation and the proposed Fourteenth Directive, will be briefly considered. The article argues that an increased mobility of companies within Europe is necessary if Europe is to remain competitive on the international level, even if the price for this is the abolition of some traditional domestic legal principles.

\section{FREEDOM OF ESTABLISHMENT WITHIN THE EUROPEAN UNION}

The freedom of establishment is a central pillar of the European Union, and is guaranteed as a fundamental right. ${ }^{4}$ Freedom of establishment is vital to eliminate barriers that national borders and

2 Council Regulation (EC) 2157/2001 on the Statute for a European Company [2001] OJ L294.

3 Klaus J Hopt Modern Company Law Problems: A European Perspective (Organisation for Economic Cooperation and Development, Paris, 2001) 3.

4 Treaty Establishing the European Community, above n 1, art 43, 48.

Article 43

Within the framework of the provisions set out below, restrictions on the freedom of establishment of nationals of a Member State in the territory of another Member State shall be prohibited. Such prohibition 
different national regulations create to the free movement of goods, services, capital and business life in general. When a national regulation is considered to be not in accordance with a principle of the Treaty on European Union, or there is uncertainty concerning the interpretation of the Treaty, inter alia, national courts have the opportunity to make a referral order to the ECJ under article 234 of the Treaty establishing the European Community. ${ }^{5}$

Article 48 is supplemented by article $294,{ }^{6}$ which provides that EU citizens shall be able to freely place capital by buying shares of companies in all Members States. The immediate purpose of this freedom is firstly, to remove the barriers that national laws pose to entrepreneurial and organisational skills of Member States' nationals and companies, and secondly, in a broader context, to advance the effective utilisation of available resources throughout the EU. ${ }^{7}$

\section{CONFLICT RULES IN INTERNATIONAL CORPORATE LAW}

\section{A Incorporation Theory}

According to the incorporation theory the law governing the activities of a company is the law of the state in which the company has been incorporated. ${ }^{8}$ Founders of a company are therefore able to choose the law that will regulate the company's statute. This theory was founded in England in

shall also apply to restrictions on the setting-up of agencies, branches or subsidiaries by nationals of any Member State established in the territory of any Member State.

Freedom of establishment shall include the right to take up and pursue activities as self-employed persons and to set up and manage undertakings, in particular companies or firms within the meaning of the second paragraph of Article 48, under the conditions laid down for its own nationals by the law of the country where such establishment is effected, subject to the provisions of the chapter relating to capital.

Article 48

Companies or firms formed in accordance with the law of a Member State and having their registered office, central administration or principal place of business within the Community shall, for the purposes of this Chapter, be treated in the same way as natural persons who are nationals of Member States.

"Companies or firms" means companies or firms constituted under civil or commercial law, including cooperative societies, and other legal persons governed by public or private law, save for those which are non-profit-making.

5 Treaty Establishing the European Community, above n 1, art 234.

6 Treaty establishing the European Community, above n 1, art 294: "Member States shall accord nationals of the other Member States the same treatment as their own nationals as regards participation in the capital of companies or firms within the meaning of Article 48, without prejudice to the application of the other provisions of this Treaty."

7 Eric Stein Harmonization of European Company Laws (Bobbs-Merrill, Indianapolis, 1971) 25.

$8 \quad$ Lawrence Collins (ed) Dicey and Morris on the Conflict of Laws (13 ed, Sweet \& Maxwell, London, 2000) 30-0 and following; Brian R Cheffins Company Law - Theory, Structure and Operation (Clarendon Press, Oxford, 1997) 427. 
the eighteenth century, allowing English companies overseas to be treated as being under English law. ${ }^{9}$ This view prevails for example, in the United Kingdom, Ireland, Finland, Sweden, the United States and Switzerland. ${ }^{10}$ Following this theory a company established according to the law of the state of incorporation will also be attributed with a legal personality, and all the rights and liabilities of a corporate existence, in other states. Thus, if the administrative centre or the statute seat of a company were relocated to a state that applied the incorporation theory, this company would be fully recognised there.

However, even in states that apply it, the incorporation theory is curtailed by creditor and shareholder protection regulations, for instance by supervision measures under administrative regulations in the United Kingdom, or by special rules for pseudo-foreign companies in the United States. ${ }^{11}$ Pseudo-foreign companies are "incorporated in one state and transacting all or most of their business in another state." ${ }^{12}$ In Western Airlines Inc $v$ Sobieski a Californian court applied Californian law to the benefit of Californian shareholders to a company that although incorporated in Delaware, was doing most of its business in California. ${ }^{13}$

In the United Kingdom, Part XXIII of the Companies Act 1985 provides for certain disclosure requirements for overseas companies, similar to the information required of a British company upon formation. Foreign companies in the United Kingdom are also governed by certain parts of the Financial Services Act 1986, by some sections of the Insolvency Act 1986, by the City Code on Takeovers and Mergers, and under certain circumstances by the provisions relating to fraudulent and wrongful trading. ${ }^{14}$

9 Jens C Dammann "Exercising Free Choice in Corporate Law" (Working Paper, 2003); Bernhard Großfeld in Staudinger: Kommentar zum Bürgerlichen Gesetzbuch, Internationales Gesellschaftsrecht (14 ed, de Gruyter, Berlin 1998) 31.

10 Großfeld, above n 9, 156 and following.

11 Stephen R Ginger "Regulation of Quasi-Foreign Corporations in California: Reflections on Section 2115 After Wilson v Louisiana-Pacific Resources" (1984) 14 SWU L Rev 665, 666. Robert R Drury "The Regulation and Recognition of Foreign Corporations: Responses to the Delaware Syndrome" (1998) 57 CLJ 165,188 and following.

12 Kurt A Strasser and Phillip I Blumberg, The Law of Corporate Groups: Tort, Contract, and Other Common Law Problems in the Substantive Law of Parent and Subsidiary Corporations (Aspen Publishers, New York, 2001) 624 .

13 Western Airlines Inc v Sobieski (1961) 191 Cal App 2d 399.

14 Paul L Davies Gower and Davies' Principles of Modern Company Law (7 ed, Sweet \& Maxwell, London, 2003) 110 . 
Proponents of this theory argue that the main benefit is legal certainty, because the statute seat of a company is easily ascertainable. In addition, it encourages the mobility of companies operating internationally. ${ }^{15}$

\section{B Real Seat Theory}

The "real seat" theory does not apply the law of the state where a company was founded, but stipulates that the law of the state where the company actually has its head office or real seat is authoritative. ${ }^{16}$ This theory evolved in France and Germany in the nineteenth century, ${ }^{17}$ primarily to keep French companies from reincorporating in Britain and Belgium. ${ }^{18}$ It is based on the consideration that the law of the state economically and politically most affected by the company's activities should apply. ${ }^{19}$ Proponents of the real seat theory argue that the incorporation theory facilitates the creation of mere letterbox companies with the consequence that government authorities cannot control business transactions properly. ${ }^{20}$

Generally, the head office or "real seat" can be defined as the place of central control where the fundamental governance decisions are effectively transformed into ongoing managerial acts. ${ }^{21}$ It is sometimes difficult to determine the company's real seat, especially if the company has no active business at the time of the relocation. However, under this theory a company can have only one head office, or seat. ${ }^{22}$ Applying the real seat principle, a relocation of a company's seat to another country would lead to the application of the law of the state the company moves to. The moving company, for example a limited liability company, has to comply with the regulations at the new seat concerning the comparable national company form. If the limited liability company does not adhere to the national regulations it will not be recognised as a legal body, consequently having no limited liability and no legal capacity. A reincorporation under the law of the new seat would be necessary.

15 Matthias Siems "Convergence, Competition, Centros and Conflicts of Law: European Company Law in the $21^{\text {st }}$ Century" (2002) 27 EURLR 47, 48.

1653 BUNDESGERICHTSHOFZ 181, 183; 97 BUNDESGERICHTSHOFZ 269, 271 and following; Großfeld, above n 9, 38 and following.

17 Guenther C Schwarz Europäisches Gesellschaftsrecht (Nomos, Baden-Baden, 2000) 179.

18 Cheffins, above n 8, 430; David Charny "Competition among Jurisdictions in Formulating Corporate Law Rules: An American Perspective on the 'Race to the Bottom' in the European Communities" (1991) 32 HVILJ 423, 428-456.

19 Peter Kindler "Niederlassungsfreiheit für Scheinauslandsgesellschaften?" (1999) 52 NJW 1993, 1994.

20 Eddy Wymeersch The Transfer of the Company's Seat in European Company Law (Working Paper, 2003) para 2.

2197 BUNDESGERICHTSHOFZ 269, 272.

22 Großfeld, above n 9, 235. 
Apart from the academic debate it has to be noted that relocation under the real seat theory with perpetuation of the company form is more expensive for the entrepreneur because of the taxes that are incurred. Under this theory there are two ways to set up the necessary new company abroad. One possibility is to establish a new company in the other Member State, which then acquires all the shares of the old company by trading its own shares, or by buying them. Alternatively, all assets may be transferred from the old to the new company. Either way the old company's shareholders, or the company itself, usually have to pay taxes for the "gained profits" from the transfer of the shares or assets. ${ }^{23}$

To sum up, the incorporation theory allows the founders to freely choose the legal system they think most appropriate and to develop activities in other states without losing the initial status of a company. The company is recognised in other jurisdictions according to the rules applicable in the state of origin. In contrast, the real seat theory enables national jurisdictions to protect their markets from pseudo-foreign companies by denying their legal status.

\section{CASES OF THE EUROPEAN COURT OF JUSTICE}

\section{$A$ Centros}

The ECJ has had occasion to rule on the freedom of establishment for companies in a number of cases. In the first decision the ECJ in effect denied a Danish authority the right to refuse to register a branch of a company validly incorporated in the United Kingdom, but which had neither conducted business nor had its seat in the United Kingdom, as a matter of freedom of establishment. ${ }^{24}$

A Danish couple, residing in Denmark, founded and registered Centros Ltd, according to United Kingdom corporate rules in $1992 .{ }^{25}$ The company never intended to conduct business in the United Kingdom; the owners only wanted to operate their business in Denmark. For this reason the owners applied for registration of a branch in Denmark. The Trade and Companies Board (Erhvervs - og Selskabsstyrelsen) refused to register Centros in Denmark, because Centros had not traded in the United Kingdom, so that effectively its main office (and not just a branch office) would be in Denmark. In other words the Danish authorities argued that, according to the real seat principle, Danish law should apply. On that basis, the Trade and Companies Board argued that Centros would be subject to Danish law and accordingly had to comply with national rules. The ECJ did not accept these arguments.

23 See Davies, above n 14, 117.

24 Case C-212/97 Centros Ltd v Erhvervs-og Selskabsstyrelsen [1999] ECR I-1459 [Centros].

25 In 1991, the minimum capital for a private limited company under Danish law (anpartsselskaber) was raised from DKK80,000 to DKK200,000, which at the time equated to approximately GBP20,000. The minimum capital was subsequently reduced to 125,000DKK in 1996. 
The ECJ held that article 52 (now 43) applied because Centros had been incorporated in the United Kingdom, where it had its registered office and sought to set up a branch in another Member State, thereby exercising the right of freedom of establishment. The fact that Centros had been set up with the sole aim of carrying out business in another state was of no relevance. The ECJ found that incorporation in a Member State whose rules of company law seem least restrictive, and setting up branches in another Member State, cannot in itself constitute an abuse of the right of establishment. ${ }^{26}$ To pursue activities only in a Member State where a branch is established "is not sufficient to prove the existence of abuse or fraudulent conduct." 27 Furthermore, national measures restricting the right of establishment are only justifiable if they are not discriminatory, justified by imperative requirements in the general interest, proportional and involve the minimum possible amount of intervention. ${ }^{28}$ Thus, the refusal to register the branch office of a company with a registered office in another Member State would amount to a breach of both articles 52 (now 43) and 58 (now 48). ${ }^{29}$

\section{B Überseering}

In a long awaited judgment, the ECJ has ruled that it is incompatible with the freedom of establishment for a Member State to deny a company formed in another Member State, which moves its real seat to this Member State, legal capacity and the standing to sue or be sued in court. ${ }^{30}$

Überseering BV, a company incorporated under Dutch law, ${ }^{31}$ had its primary seat in the Netherlands. The German cadastral register regarded it as the owner of a hotel. Überseering assigned a company to redevelop the buildings and claimed afterwards that the work was defective. Meanwhile, two German citizens had acquired all the shares in the plaintiff. Since then the company had its real seat in Germany. Consistent with German case law and prevailing opinion, the Landgericht (District Court) dismissed the action brought by Überseering due to procedural inadmissibility. It held that the plaintiff, as a company under Dutch law, with its real seat in Germany, had no legal capacity and no standing to sue under German law, because it was not (re)formed under German law. The Oberlandesgericht (High District Court) upheld the decision. ${ }^{32}$

26 Centros, above n 24, para 27.

27 Centros, above n 24, para 29.

28 Centros, above n 24, para 34; see also Case C-167/01 Kamer van Koophandel en Fabrieken voor Amsterdam v Inspire Art Ltd [2003] ECR I-10155 [Inspire Art] para 133.

29 Centros, above n 24, para 39.

30 Case C-208/00 Überseering BV v Nordic Construction Company Baumanagement GmbH [2002] ECR I9919 [Überseering].

31 "BV" is the Dutch legal form for a private limited company.

32 OLG Düsseldorf Fifth Civil Court of Appeal (10 September 1998). 
The case went to the Bundesgerichtshof (German Federal Court of Justice) on appeal. The prevailing case law of the Bundesgerichtshof at the time denied legal capacity, and hence the capacity to sue or be sued before a German court, to companies formed under foreign law, which subsequently moved their real seats to Germany, unless these companies reincorporated under German law. ${ }^{33}$ The Bundesgerichtshof during the appeal decided to stay proceedings and referred the case to the ECJ under article 234 of the EC Treaty.

The ECJ reaffirmed the principle established in Centros that companies incorporated in a Member State are entitled to carry on their business in another. A necessary precondition for such exercises of freedom of establishment is that those companies be recognised by any Member State in which they choose to establish themselves.

The supporters of the real seat principle relied on the dicta of the ECJ in the Daily Mail case, ${ }^{34}$ which they claimed supported the view that a company exists only by virtue of the domestic law, which in turn determines that company's legal capacity and functioning. ${ }^{35}$ This interpretation was rejected by the ECJ. Daily Mail was held to be irrelevant, dealing as it did with a wholly unrelated relationship between the home state and a company that intended to transfer its centre of administration to another Member State to avoid taxation in the original home state. ${ }^{36}$

The ECJ found that the German position effectively required a company to be reincorporated in Germany before its rights could be enforced, ${ }^{37}$ and was "therefore tantamount to outright negation of freedom of establishment."138 The Court also rejected the argument that the restriction of establishment was justified by the overriding requirements of general interest. However, the ECJ stated: 39

It is not inconceivable that overriding requirements relating to the general interest, such as the protection of the interests of creditors, minority shareholders, employees and even the taxation authorities, may, in certain circumstances and subject to certain conditions, justify restrictions on freedom of establishment.

33 Kilian Baelz and Teresa Baldwin "The End of the Real Seat Theory: the ECJ Decision in Ueberseering and its Impact on German and European Company Law" (2002) 12 German Law Journal, para 5.

34 Case C-81/87 The Queen v H M Treasury and Commissioners of Inland Revenue, ex parte Daily Mail and General Trust Plc [1988] ECR I-5483 [Daily Mail] The Court held at para 19: "In that regard it should be borne in mind that, unlike natural persons, companies are creatures of law and, in the present state of Community law, creatures of national law. They exist only by virtue of the varying national legislation which determines their incorporation and functioning".

Überseering, above n 30, para 29 and following

36 Überseering, above n 30, para 62, 72, 73 .

37 Überseering, above n 30, para 79.

38 Überseering, above n 30, para 81.

39 Überseering, above n 30, para 92. 
The ECJ also held that if a company incorporated in one Member State exercises its freedom of establishment in another Member State, this state is required to recognise the company's legal capacity under the laws of the State of incorporation. ${ }^{40}$

Following the ECJ judgment, the Bundesgerichtshof overruled the decisions of the Landgericht and the OLG Düsseldorf in 2003, deciding that Überseering BV had legal capacity and the right to sue in German courts. The case was remanded to the Oberlandersgericht. ${ }^{41}$

\section{Inspire Art}

In recent decisions, the ECJ has continued to rule in favour of the freedom of establishment by holding that rules submitting foreign companies to the company law of the host state were inconsistent with EC law.

Inspire Art Ltd was a company founded in the United Kingdom. Immediately after its formation the company started operating in the Netherlands, where its sole shareholder and director lived. No business was ever conducted in the United Kingdom and the shareholder only intended to take advantage of the liberal rules of British company law. A company branch was then registered with the Amsterdam Chamber of Commerce without indicating that Inspire Art was a pseudo-foreign company. Such an indication, however, was necessary according to the Wet op de formeel buitenlandse vennootschappen $(W F B V) .{ }^{42}$ As a "formally foreign company", Inspire Art Ltd was obliged to comply with the provisions of articles 2 to $5 W F B V$ that, besides numerous further disclosure requirements, stipulated a minimum capital. According to $W F B V$, the company's subscribed capital had to be at least equal to the minimum amount that article 178 Burgerlijk Wetboek required for Dutch companies with limited liability, ${ }^{43}$ being 18,000 EUR. If minimum capital requirements are not met, Dutch law holds company directors liable as joint and several debtors for the company's debts.

The Kantongerecht Amsterdam (Amsterdam District Court) held in its decision in 2001 that Inspire Art Ltd was a pseudo-foreign company within the meaning of article $1 W F B V$ and referred the case to the ECJ for a preliminary ruling on whether the $W F B V$ regulations were consistent with the EC Treaty. ${ }^{44}$

40 Überseering, above n 30, para 93.

41 BUNDESGERICHTSHOF VII ZR 370/98 (13 March 2003).

42 Dutch law on pseudo-foreign companies.

43 Dutch Civil Code.

44 Christian Kersting and Clemens P Schindler "The ECJ's Inspire Art Decision of 30 September 2003 and its Effects on Practice" (2003) 12 German Law Journal, para 4. 
The ECJ again decided clearly in favour of the freedom of establishment. The Court ruled that article $1 \mathrm{WFBV}$, stating that Dutch branches of pseudo-foreign companies must disclose that they are pseudo-foreign companies, was in breach of the Eleventh Council Directive, ${ }^{45}$ because the latter did not permit any disclosure rules going beyond the rules contained in it. The ECJ reasoned that since the Directive gave the Member States discretion to introduce specifically enumerated additional disclosure requirements, the listing of potential disclosure requirements in article 2 of the Directive is exhaustive. ${ }^{46}$ The Court held that a requirement corresponding to the Dutch provision could be found in neither the list of the obligatory requirements nor of the facultative disclosure requirements of the Eleventh Council Directive and was therefore inconsistent with EC law. Given this fact, the Court deduced that justification of such provisions was not possible. ${ }^{47}$

The Court held that the provision requiring pseudo-foreign companies to have capital at least equivalent to the minimum capital prescribed for Dutch limited liability companies to exclude the personal liability of their directors, constituted a violation of the freedom of establishment. Such a provision could not be justified by public interest because neither article 46 of the EC Treaty, ${ }^{48}$ nor the protection of creditors, the prevention of an improper recourse to freedom of establishment, the enforcement of fairness in business dealings, nor the efficiency of tax inspections could be invoked in this case. ${ }^{49}$ The Court pointed out that Inspire Art Ltd held itself out to be a foreign and not a Dutch company, and therefore its creditors were sufficiently informed that it was subject to provisions other than those applying to a limited liability company formed under Dutch law. ${ }^{50}$

The ECJ further concluded that the incompatibility of the minimum capital provisions with the freedom of establishment inevitably resulted in the relevant sanctions being incompatible with Community law as well, and that no further examination was necessary in this respect. ${ }^{51}$ To form a company for the purpose of circumventing national laws regarding minimum capital is not sufficient

45 Eleventh Council Directive (EEC) 89/666 Concerning disclosure requirements in respect of branches opened in a Member State by certain types of company governed by the law of another State [1989] OJ L395.

Inspire Art, above n 28, para 67-72.

47 Inspire Art, above n 28, para 106.

48 Treaty establishing the European Community, above n 1, art 46(1) EC reads: "The provisions of this chapter and measures taken in pursuance thereof shall not prejudice the applicability of provisions laid down by law, regulation or administrative action providing for special treatment for foreign nationals on grounds of public policy, public security or public health. "

49 Inspire Art, above n 28, para 142.

50 Inspire Art, above n 28, para 135.

51 Inspire Art, above n 28, para 141. 
to prove the existence of abuse or fraudulent conduct justifying the denial of the right of establishment. $^{52}$

\section{CONSEQUENCES OF THE ECJ JUDGMENTS FOR EUROPEAN COMPANY LAW}

\section{A The Real Seat Principle}

One shortcoming of the ECJ judgments is that they do not contain a clear statement about the different conflict of laws rules for companies in Europe. The discussion and flood of publications after each judgment are due to the fact that there was no definite pronouncement concerning the real seat principle. The ECJ decisions are solely based on arguments relating to the freedom rights provided by the EC Treaty. The cases fail to deal expressly either with conflict of laws rules, or with company law as such. Nevertheless, the aforementioned cases constitute important landmarks on the road towards the free circulation of companies in Europe.

After the Centros decision the contrast between the real seat principle and the incorporation principle became more controversial. In countries applying the real seat principle academic debate flourished about the extent to which the ECJ decision undermined the real seat doctrine. Scholars argued that the decision was far from groundbreaking, rather reaffirming the parallel prevalence of the theories of real seat and of incorporation. For example, Kindler stated: "The judgment has no relevance for Member States that apply the real seat theory." ${ }^{53}$ Characterising Centros Ltd as a national company would be justified by the common practice of these states, which is to connect the nationality of a company with the place where the company's real seat is located. ${ }^{54}$ But the Centros case was more far-reaching than some courts and commentators from states applying the real seat doctrine realised. ${ }^{55}$ Other scholars greeted the decision as a rejection of the real seat principle, concluding that it contradicts the general policy of freedom of establishment under the EC Treaty. ${ }^{56}$

The Überseering rulings fitted well with Centros. After Überseering voices clamoured more insistently that the real seat principle was inconsistent with the freedom of establishment under EU

52 Inspire Art, above n 28, paras 136-139.

53 Kindler, above n 19, 1996.

54 Kindler, above n 19, 1996 and following; Helen Xanthaki "Centros: Is it Really the End for the Theory of Siege Reel (2001) 22 Comp Law 2, 7.

55 Stephan Rammelloo Corporations in Private International Law: A European Perspective (Oxford University Press, Oxford, 2001) 72 and following.

56 Erik Werlauff "Using a Foreign Company for Domestic Activities" (1999) 10 European Business Law Review 306, 310; Ilan Rappaport "Freedom of Establishment - A New Perspective" (2000) JBL 628, 633; Cheffins assumed even before Centros that the real seat principle was inconsistent with the freedom of establishment, see Cheffins, above n 8, 430 and following. 
law. ${ }^{57}$ However, it was argued that the real seat principle could still be applied as long as the pseudo-foreign company's legal capacity, but not limited liability, was recognised, which could be achieved if a foreign company was treated as a Gesellschaft bürgerlichen Rechts $(G b R) .{ }^{58}$ It appeared that the measures under fire were all measures to protect national economies and jurisdictions against pseudo-foreign companies. ${ }^{59}$ Following Inspire Art there was at least wide consensus that the real seat principle no longer applied to cases where companies moved to another Member State. Commentators realised that from a freedom of establishment perspective it would make no difference whether the legal consequence of unlimited liability would arise ipso jure, as it would under the German approach, or from the registration as a pseudo-foreign company under Dutch law. ${ }^{60}$ Consequently, companies of other Member States have to be acknowledged as "a whole", not just in their legal capacity. ${ }^{61}$

The judgments call for mutual recognition of companies' legal personalities by way of judicial practice of Member States' courts. This may cause legislative activity to bring about overdue harmonisation of company law in the EU and the abolition of obstacles for a free internal market for companies. ${ }^{62}$

\section{B Justifiable Exceptions}

When the ECJ examined whether the Danish restrictions in Centros were justified, it found that imperative requirements in general might be a possible justification for Member States to confine the freedom of establishment. The Court set out and reaffirmed in the subsequent cases four conditions under which a restriction of the freedom of establishment might be justified: the restricting measure must be applied in a non-discriminatory way, justified by imperative requirements in the public interest, able to achieve the object, and necessary and proportionate. ${ }^{63}$

57 Dominic E Robertson "Überseering: Nailing the Coffin on Sitztheorie" (2003) 24 Comp Law 184; Peter Dyrberg "Full Free Movement of Companies in the European Community at Last" (2003) 28 El Ref 528, 535; Martin Schulz and Peter Sester "Höchstrichterliche Harmonisierung der Kollisionsregeln im Europäischen Gesellschaftsrecht: Durchbruch der Gründungstheorie nach 'Überseering'" (2002) 13 EWS 545 and following.

58 Peter Kindler "Auf dem Weg zur Europaeischen Briefkastengesellschaft?" (2003) NJW 1073, 1076 and following; LG (District Court) Frankenthal 1 HKT 9/02 (6 December 2002). This decision is unsustainable after Inspire Art and was already questionable after Centros; Gesellschaft bürgerlichen Rechts: Company under the German Civil Code.

59 Dyrberg, above n 57, 535

60 See for example Daniel Zimmer "Nach 'Inspire Arts': Grenzenlose Gestaltungsfreiheit fuer deutsche Unternehmern?" (2003) 56 NJW 3586.

61 Zimmer, above n 60, 3591.

62 Dyrberg, above n 57, 537.

63 Centros, above n 24, para 34; Überseering, above n 30, para 34; Inspire Art, above n 28, para 133. 


\section{Minimum capital}

The Danish measures were dismissed because the Court held they were neither suitable nor proportionate for attaining these aims. The Court held that the Danish practice did not effectively protect creditors, because "if the company concerned had conducted business in the United Kingdom, its branch would have been registered in Denmark, even though Danish creditors might have been equally exposed to risk." ${ }^{64}$ The question remains what kind of measures can be justified? It goes to the core of an important debate in European company law, concerning how to protect creditors from the risk arising out of limited liability.

The Danish authorities argued that the minimum capital requirement promotes the protection of public and private creditors. ${ }^{65}$ Public creditors like tax authorities or social insurance institutions cannot demand securities to hedge receivables, and therefore have to be protected by laws controlling the solvency of companies. ${ }^{66}$ Minimum capital requirements are said to reduce the risk of fraudulent bankruptcy, or bankruptcy due to capital that was initially inadequate, and thus protect private creditors as well. In contrast, the ECJ held Danish creditors were also exposed to the same risks when dealing with United Kingdom companies which trade in the United Kingdom and Denmark. Further, the Court reasoned that Centros was evidently established as a limited company under British law, and its creditors were sufficiently informed that Danish regulations did not apply. 67

This reasoning is questionable because it requires business people of all levels to be familiar with various company laws throughout the EU. It also fails to take into consideration the fact that private limited companies from different Member States may have the same appellation but different amounts of minimum capital. For example, private limited companies under Austrian and under German law are both called Gesellschaft mit beschränkter Haftung (GmbH). The Austrian company is required to have a minimum capital of EUR $35,000,{ }^{68}$ while the German counterpart is only required to have a minimum capital of EUR $25,000 .{ }^{69}$ A Swiss private limited company can operate under the same name and is required to have a minimum capital of about EUR 13,000. ${ }^{70}$

64 Centros, above n 24, para 35.

65 Centros, above n 24, para 12.

66 Eva Micheler "The Impact of the Centros Case on Europe's Company Laws" (2000) 21 Comp Law 179, 180

67 Centros, above n 24, para 36.

68 Österreichisches GmbH Gesetz, s 6(1) (Austrian law on private limited company).

69 Deutsches GmbH Gesetz, s 5(1) (German law on private limited company).

70 Schweizer Obligationenrecht SR 220 OR, art 773 (Swiss Civil Code). The amount specified is SFR 20,000. 
However, lawyers, especially from Austria and Germany, expressed concern that the findings of the ECJ would make the company laws of jurisdictions requiring a minimum capital redundant. ${ }^{71}$

The continental European idea of minimum capital is that a shareholder has to pay a certain amount into the company in order to gain limited liability. ${ }^{72}$ Further rules ought to secure that that capital is preserved throughout the company's existence to ensure the company has sufficient funds to start and carry out its business. But these rules might be considered ineffective. ${ }^{73}$

In comparison, English company lawyers traditionally tend to regard minimum capital for private limited companies as ineffective for creditor protection, even harmful for the economy, because they prevent companies from being established. ${ }^{74}$ Furthermore, scholars argue that minimum capital requirements should not depend solely on the type of company, whether it is a private or a public company, but on the level of risk the company undertakes. ${ }^{75}$ This seems a sound argument but the inherent practical problems should not be underestimated, because it is very difficult to assess the level of risk of a business from an ex ante perspective. Markets alter very quickly, and a change in the company's policies or management might affect the minimum capital. Ultimately, a minimum capital requirement at the time the company commences trading does not guarantee any particular level of assets being available for the creditors at a later date. Over time effective creditor protection decreases because of the erosion of capital in the course of trading. For this reason Anglo-American legislations and their corporate lawyers rely on rules requiring directors to take creditors' interests into account as the company heads towards insolvency. ${ }^{76}$

The debate will probably continue but it has already lost its practical relevance. Following the ECJ findings in Centros, the Oberster Gerichtshof (Austrian Supreme Court) in 1999 allowed Austrian citizens to register branches of private limited companies under United Kingdom law in Austria, even if they did not carry out any business in the United Kingdom. ${ }^{77}$ For governments within the EU it is no longer possible to keep "cheap" limited liability companies out of their jurisdictions and economies. Bearing the aforementioned criticism in mind, the abolition of the

71 Micheler, above n 66, 180.

72 For example, for private limited companies the required amounts are: Austria EUR 35,000, Belgium EUR 18,550, Czech Republic CZK 200,000 (approximately EUR 6000), France EUR 7620, Germany EUR 25,000, Italy EUR 10,000, Latvia LVL 2000 (approximately EUR 3090), Spain EUR 3006, Switzerland SFR 20,000 (approximately EUR 13,000).

73 Davies, above n 14, 229 and following; Siems, above n 15, 58.

74 Department of Trade and Industry Modern Company Law for a Competitive Economy: Strategic Framework: Consultation Paper (London, 1999) 81 and following.

Davies, above n 14, 229

76 Davies, above n 14, 230.

77 OGH (15 July 1999) 6 Ob 124/99 and 6 Ob 123/99b. 
minimum capital requirement seems not to be a great disadvantage for creditors, since it has, among other shortcomings, never guaranteed any assets in case of insolvency.

\section{Threatening insolvency}

It remains unclear whether the duty to commence insolvency proceedings in time can be imposed on directors and managers of pseudo-foreign companies as an overriding reason of creditor protection in the general interest. Particularly questionable is the penalty that German company law, for example, imposes for belated application for insolvency proceedings. ${ }^{78}$ In cases of culpably late insolvency proceedings directors face criminal punishments which may include imprisonment. Some Member States have similar regulations, but when the matter concerns directors of companies governed by the company law of other Member States this might be an illegal penal analogy. ${ }^{79}$ Penal analogies generally contradict the principle of nulla poena sine lege (no punishment without law) and are therefore forbidden in most jurisdictions. For this reason an application of the special rules seems to be barred. A possible alternative would be to bring a claim under the liability principles of general tort law, which would only lead to monetary penalties.

\section{Co-determination}

The participation of employees might be another possible exception courts could consider as a justified limitation to companies' freedom of establishment. In Germany particularly, this is a highly political topic and the domestic government is likely to try to impose the regulations on any company that operates in Germany. Co-determination will be more fully developed later in this paper. ${ }^{80}$

\section{Individual abuse}

At this point the only clear justifiable restriction on the freedom of establishment concerns the establishment of foreign companies with fraudulent intent, whereas having the sole intention of circumventing minimum capital requirements is insufficient. ${ }^{81}$ Fraudulent abuse of the freedom of establishment for companies would have to be verified individually in every single case. A possible example could be the withdrawal of assets from a company by a shareholder without compensation, causing the economic breakdown of the company. Some commentators argue that it would be consistent with the freedom of establishment to apply liability regulations from domestic company

78 See art 84 GmbHG German law on private limited companies (Gesetz betreffend die Gesellschaften mit beschaenkter Haftung [GmbHG]) and art 401 German companies Act (Aktiengesetz [AktG]).

79 Zimmer, above n 60, 3590.

80 See Part VI B Co-determination.

81 Inspire Art, above n 28, para 136-139. 
law to foreign companies in cases like this. ${ }^{82}$ However, governments may define a restriction on the freedom of establishment. It can be inferred from ECJ rulings that the Court will uphold a strict standard, and place considerable emphasis on the proportionality requirement. ${ }^{83}$

\section{Fourteenth Council Directive}

The preamble of the pending Fourteenth Council Directive on the transfer of the registered office of a company from one Member State to another with a change of applicable law notes that "the objective of making it possible for a registered office to be transferred cannot be satisfactory achieved by the Member States in isolation". ${ }^{84}$ The proposal was an attempt by the Council to address this issue in 1997, but it has not yet been implemented and does not involve harmonising the different conflict of laws rules. Member States applying the real seat principle can continue to do so, and Member States applying the foundation theory can also continue to do so. ${ }^{85}$ The Directive's aim is to enable a company to transfer its registered office from one Member State to another while retaining its original legal personality, enabling a cross-border relocation without winding-up, but changing the law applicable to the company. After the transfer, the company will be subject to the law of the host country. The proposal only covers companies with share capital, because these are the only companies that have legal personality in all Member States. It does not address consequences for taxation, which will affect the former home state. The proposal appears redundant after the latest ECJ judgments concerning companies' freedom of establishment. The rules established by the ECJ go much further than the Directive's proposed regulations. In comparison, the ECJ approach does not require a change in the law governing the company. This means less bureaucratic work and less costs for the moving company.

\section{Company Law Shopping}

One crucial consequence of the abovementioned ECJ judgments is that founders within the EU are now free to choose the company law they prefer. The question that arises from this fact is: will the private limited company under United Kingdom law supersede the private limited companies under the law of other Member States? In the United States the incorporation principle applies between the States in the Federation. In practice, the State of Delaware has become most attractive for incorporating companies. It is disputed whether it is due entirely to the lax company law of

82 For example, the German so-called existence-annihilation-liability (Existenzvernichtungshaftung); Norbert Horn "Deutsches und europäisches Gesellschaftsrecht und die EuGH-Rechtsprechung zur Niederlassungsfreiheit - Inspire Art" (2004) 57 NJW 893, 899; Zimmer, above n 60, 3588.

83 Wymeersch, above n 20, para 36.

84 Proposal for the Fourteenth Council Directive on the transfer of the registered office of a company from one member state to another with a change of applicable law (1997) XV/D2/6002/97-EN REV2.

85 Proposal for the Fourteenth Council Directive, above n 84. 
Delaware, or whether other factors also come into play. ${ }^{86}$ There is, at least, a consensus that lenient corporate law is one reason for the large number of companies registered in Delaware. For example, Delaware corporate law allows the possibility of the elimination of directors' liability for negligence. Liberal rules also allow changing the choice of the law under which the company should be subsequently established. This has led to a situation where more than half a million companies are incorporated in Delaware, including almost 60 per cent of the Fortune 500 and 50 per cent of the companies listed on the New York Stock Exchange. ${ }^{87}$

This sensation, known as the "Delaware effect", concerns mainly listed companies. Since the Second Company Law Directive provides for a minimum capital of EUR 25,000 and capital maintenance for public limited companies, ${ }^{88}$ as distinct from private limited companies, where there is no such requirement under EU law, the incentive of not having to pay in a certain amount of capital does not apply to public companies. A situation like that in the United States is unlikely to occur to the same degree in the EU. For example, the Plc under United Kingdom law requires a minimum capital of GBP 50,000 (approximately EUR 75,000) and the Aktiengesellschaft $(A G)^{89}$ requires EUR 50,000. Scholars also bring forward the argument that a company targeting institutional investors cannot afford to be incorporated under a legal system that falls short of the basic rules of shareholder and stakeholder protection. ${ }^{90}$ Even if cross-border legal advice is easily available and English is the main business language, different languages, and legal and cultural traditions might in addition decelerate the effect to a certain degree. ${ }^{91}$

These arguments apply mainly for bigger businesses in the form of public limited companies. For smaller businesses in the form of private limited companies, the race has already begun. The private limited company is an important vehicle, especially for medium-seized businesses. For example, in October 2003 there were about 800,000 private limited companies registered in

86 Lucian A Bebchuck "Federalism and the Corporation: the Desirable Limits on State Competition in Corporate Law" (1992) 105 Harv LR 1435, 1444 and following; Charny, above n 18, 430 and following.

87 State of Delaware Division of Corporations <http://www.delaware.gov> (last accessed 22 July 2005); Active Filings $<$ http://activefilings.com/states/delaware $>$ (last accessed 22 July 2005).

88 Second Council Directive (EEC) $77 / 91$ on coordination of safeguards which, for the protection of the interests of members and others, are required by Member States of companies within the meaning of the second paragraph of Article 58 of the Treaty, in respect of the formation of public limited liability companies and the maintenance and alteration of their capital, with a view to making such safeguards equivalent [1976] OJ L26.

89 Public limited company under German law.

90 Bealz and Baldwin, above n 33, para 35.

91 Siems, above n 15, 47. 
Germany, but only 4000 public limited companies of which less than 800 were quoted on the stock exchange. ${ }^{92}$

For smaller businesses it is quite an incentive not to have to pay in a minimum capital in the start-up phase. Since shares of private limited companies are not usually publicly traded, the reputation of the governing corporate law is not as important in attracting investors. Certainly, the ECJ decisions will lead to some competition among company laws which will invariably result in some forced harmonisation of EU law. ${ }^{93}$ The private limited company under United Kingdom law will become, or already is, an export bestseller. For example, the number of companies founded every two weeks under United Kingdom law increased from an average of 5,500 to 7,000 immediately following the Überseering decision. ${ }^{94}$ French legislators have already reacted to the "corporate law challenge". By introducing the one-euro SARL in August 2003 France made available a legal form without a minimum capital, comparable to the private limited company under United Kingdom law, thereby preventing emigration of domestic companies to the United Kingdom, and securing the application of French law and its future design. ${ }^{95}$

Minimum capital requirements are only one factor in the decision about which company law to choose. Other factors include disclosure requirements, directors' liabilities and lower incorporation fees. The rules regulating the relationship between management and shareholders are another important consideration. For example, the Netherlands has, like Delaware in the United States, some management preferring rules. For instance, managers are allowed to control large amounts of votes by placing the shares in company-owned trusts. ${ }^{96}$ This practice is usually forbidden in other jurisdictions.

In the United States there is discussion whether it is necessary to expand federal regulations to protect shareholders and to avoid a "race to the bottom". ${ }^{97}$ Proponents of a federal regulation argue that managers generally decide where to incorporate or reincorporate. The state with the most lenient corporate laws concerning duties of managers will be favoured. Shareholders may be poorly informed about the changes to their rights following the change in applicable company law as a

92 "Private European Company Data and Financials: Comparative Review of AMADEUS and Global Business Browser: European Edition" (1 December 2003) VIP Ashford (UK) 5.

93 Siems, above n 15, 47.

94 Heribert Hirte "Wettbewerb der Rechtsordnungen nach 'Inspire Art"' < http://www.gmbhr.de> (last accessed 2 August 2005).

95 Patricia Becker "Verabschiedung des Gesetzes über die französische Blitz-SARL" (2003) 19 GmbHR 1120 and following.

96 Charny, above n 18, fn 20.

97 This expression was first used by Justice Brandeis in Ligett v Lee (1933) 288 US 517, 557 and following. 
result of the relocation of the company's seat. ${ }^{98}$ Opponents object that market forces will prevent managers from seeking incorporation in states with laws that are harmful to investors and allow the management to trick shareholders. ${ }^{99}$ They argue that managers will incorporate in a country whose corporate laws are most efficient from the shareholders' point of view. According to these commentators, Delaware does not attract companies because its laws are lax, but because they are efficient. As indicated below, there are some difficulties with this point of view.

United States federal courts are consistently more rigorous than the courts of Delaware when applying the same basic legal standards. From a manager's point of view, Delaware is attractive because of its anti-takeover statutes, the possibility of the exclusion of negligence liability and its cursory examination of merger, spin-off or recapitalisation decisions. ${ }^{100}$

Some scholars argue that the public image of a company may be enhanced if it is established in a state with strict rules, to signal to the market that the company is a reliable business partner. ${ }^{101}$ This might be true in a few cases, but, as the example of Delaware shows, it will not be decisive for the majority. Some corporations will take advantage of the opportunity to (re-)incorporate in a foreign Member State. In Europe the number of rules that serve third parties or stakeholders will decrease because they are a hindrance to competitiveness, but it is still within the EU's mandate to regulate these matters. The late developments will, in any case, not lead to a situation similar to that in the United States, since it is likely that established businesses, big ones in particular, will stay where they are. The number of important factors to be considered when deciding where to incorporate is not as high in the EU as in the United States, and the benefits of incorporating in one state as opposed to another are also of less consequence.

\section{E Treatment of Companies from Non-Member States}

Recognition of foreign companies is not only a problem within the EU. Since the ECJ only has a mandate to judge matters between EU Member States, the handling of companies that were established in non-Member States is still the responsibility of national courts as long as there is no EU regulation dealing with this issue. As article 48 of the EC Treaty states, a company must be established under the law of a Member State and have its "registered office" or "central

98 Bebchuck, above n 86, 1500; Charny, above n 18, 431; see generally Drury, above n 11, 185 and following.

99 Peter Dodd and Richard W Leftwich "The Market for Corporate Charters: Unhealthy Competition vs. Federal Regulation" in Richard A Posner and Kenneth E Scott (eds) Economics of Corporation Law and Securities Regulation (Little Brown, Boston, 1980) 100 and following; Amanda Acquisition Corp $v$ Universal Food Corp (1989) 877 F 2d 496, 507 Easterbrook J ( $7^{\text {th }}$ Cir).

100 Charny, above n 18, 432 and following.

101 Christian Kersting and Clemens P Schindler "Die EuGH-Entscheidung 'Inspire Art' und ihre Auswirkungen auf die Praxis" (2003) RdW 11 621, 625; Siems, above n 15, 54. 
administration" or "principal place of business" within Europe to enjoy the rights and privileges of the EC Treaty.

After Überseering the Bundesgerichtshof issued another judgment, concerning the legal capacity of a corporation that was established in the United States. ${ }^{102}$ Because of the Treaty of Friendship, Commerce and Navigation between the United States and Germany of 29 October $1954,{ }^{103}$ the Court held that a company established in the United States has legal capacity in Germany no matter where its real seat is located. The Bundesgerichtshof usually applied, according to German international company law, the real seat principle, but stated that it is possible to depart from this doctrine if there is a treaty in force. ${ }^{104}$ Article XXV of the United States - German Treaty, inter alia, guarantees national and most-favoured-nation treatment for companies constituted within the territory of either party. In its judgment, the Bundesgerichtshof cited the Überseering decision of the ECJ and followed its argumentation, leading to the conclusion that the Bundesgerichtshof will apply the rules on freedom of establishment set out by the ECJ to companies established in a non-Member State if there is a treaty in force with the state of incorporation that guarantees national or mostfavoured-nation treatment. This is a step towards free movement of companies outside the EU. Sooner or later national courts in the EU will apply the foundation principle to all companies immigrating into a Member State. As this is a political discussion, bearing in mind the disputes concerning minimum capital or co-determination, which will be addressed later, ${ }^{105}$ most European legislators will need some time to accept and implement the inevitable.

\section{F Findings}

The EU is intended to be based on mutual trust and respect. Keeping this in mind, the aforementioned judgments and the resulting consequences are a huge step forward. There is no reason to assume that the laws of one Member State are inferior to the laws of other Member States. Once a company has been lawfully established it may carry out business elsewhere. Since business people and company founders have the right to choose in practice, what best meets their needs will prevail.

The freedom of establishment under the current definition of the ECJ still does not cover the freedom to move away from a certain Member State; the freedom to emigrate. ${ }^{106}$ In Daily Mail the

102 Bundesgerichtshof VIII ZR 155/02 (29 January 2003).

103 Treaty of Friendship, Commerce and Navigation between the United States of America and the Federal Republic of Germany (29 October 1954) Bundesgesetzblatt (German Federal Law Gazette) II 1956487.

104 See EGBGB (Introductory law to the German Civil Code) art 3, s 2, sentence 1.

105 See Part VI B Co-determination.

106 Bealz and Baldwin, above n 33, para16; Überseering, above n 30, para 62. 
ECJ reasoned that emigration is not a cross-border issue. ${ }^{107}$ Accordingly, it is left to national jurisdictions to deal with emigration issues, meaning national regulators can still impose substantial restrictions on domestic companies, and thus hamper the free movement of companies within Europe. ${ }^{108}$ This is somewhat inconsistent with the broad understanding of the freedom of establishment on which the ECJ has based its decision in the aforementioned cases, and with the freedom of movement of natural persons. So far this seems to be more of a potential problem depending on how the ECJ interprets future emigration cases and if the Court is willing to decline the Daily Mail approach.

The freedom of movement of individuals is the point of reference in article 48 that says "companies ... shall ... be treated in the same way as natural persons who are nationals of Member States." 109 In Überseering the ECJ drew a parallel between the freedom of establishment and the rules relating to the free movement of capital. ${ }^{110}$ The free movement of capital under the Treaty requires free movement both ways, in and out of a Member State. Strict application of this thought would lead to equal treatment of cases of emigration and immigration of companies. ${ }^{111}$ To achieve a community-wide freedom of establishment the restraints for companies that want to emigrate to another Member State must also be abolished. It appears that the ECJ was unwilling to contradict its own findings in the earlier Daily Mail decision. ${ }^{112}$ It remains to be seen how the ECJ will handle this problem in future decisions.

\section{CONSEQUENCES FOR RELATED LEGAL AREAS}

\section{A Tax Law}

The possibility of saving taxes has great appeal for companies intending to establish in a certain state. Government revenues from incorporation fees, additional fees for amendments, and annual franchise taxes are important in the United States. More than 20 per cent of all tax revenues in Delaware result from this. ${ }^{113}$ The fees and taxes in Delaware do not differ considerably from those in other parts of the United States. So, while fees and taxes are no incentive for companies, they are for the State's government. This might be seen as an incentive for European governments to install a lax corporate law to attract companies to establish in their countries. However, in Europe, unlike in the United States, Member States do not earn significant amounts of money from incorporating

107 Daily Mail, above n 34, para 18, para 25; Wymeersch, above n 20, para 22.

108 Wymeersch, above n 20, para 22.

109 See full text of art 48, above n 4 .

110 Überseering, above n 30, para 77.

111 Schulz and Sester, above n 57, 550.

112 See Daily Mail, above n 34.

113 Siems, above n 15, 57. 
businesses, since there are no annual franchise taxes, or yearly incorporation fees. Furthermore, tax has its own legal regime autonomous from corporate law.

Corporate income tax varies within the EU. ${ }^{114}$ However, since the place of central management and control is decisive for the taxation of companies in both countries that apply the real seat principle and countries that apply the incorporation theory, the ECJ judgments did not offer new opportunities as regards taxes. ${ }^{115}$ Furthermore, there are double tax treaties throughout the EU.

After the ECJ's Centros decision, the Danish Parliament adopted a law that takes advantage of the real seat principle being applicable in tax law. The act introduced a new minimum capital requirement embodied in tax law for companies operating in Denmark. ${ }^{116}$ It applies to companies registered in Denmark, but also to companies with their real seat in Denmark. Either way, companies must put up a guarantee of DKK110,000 in favour of the Danish tax office, or state that the company at the time of registration with the Danish tax authorities has net assets of at least DKK 125,000 , which is the amount of the minimum capital required for a private limited company under Danish law. Neither guarantee, nor capital statement is necessary if at least one natural person is fully liable. ${ }^{117}$ This example shows that governments with a long-lasting minimum capital tradition are unwilling to give up this measure and are looking for ways to circumvent the Centros decision.

It remains to be seen whether this minimum capital requirement under the tax law regime will be contested and if so, whether the ECJ will see it as being consistent with the freedom of establishment. According to the ECJ's broad understanding of the freedom of establishment and its strict application of the necessity and proportionality requirements, it seems unlikely that the ECJ would allow the Danish regulation.

\section{B Co-determination}

One of the most controversial issues for European company law harmonisation has been the extent of co-determination. Thus, the question of employee participation in management remains an important factor for the decision of where to incorporate, as long as the Fifth Council Directive regarding unitary and two-tier board structures and the question of whether employee representation on one board should be mandatory is still pending. ${ }^{118}$ From 1972 to 1988 , three different drafts of

114 Basic rates of corporate income tax: France 33.3\%, Germany 25\% (until the year $200040 \%$ if retained and $30 \%$ if distributed), Italy $36 \%$, Slovenia $25 \%$, United Kingdom 30\% (19\% for small companies).

115 Siems, above n 15, 52; Daily Mail, above n 34, para 4.

116 L 212 Act No 461 (31 May 2000).

117 For example, in a partnership.

118 Draft Fifth Council Director [1983] OJ C240 (proposal with subsequent amendments). 
this Directive have been issued. ${ }^{119}$ The Directive has not been adopted, mainly because of substantial differences in the degree of worker participation, ${ }^{120}$ since it basically tried to stipulate mandatory employee participation for companies of all Member States with more than 500 employees. ${ }^{121}$ Co-determination is understood by promoters to benefit society as a whole by taking into account employee interests for structural and strategic management decisions. Opponents argue co-determination reduces shareholder value, since it is an additional burden for managers and requires time-consuming negotiations within the company.

Co-determination does not necessarily affect establishing a company, therefore it is not an essential feature of company law, but it affects certain company forms like the $A G$ and it can also affect other company forms, if these companies exceed a threshold of employees. Since codetermination laws supercede company law in Germany, ${ }^{122}$ it is an important consideration when establishing a company in Germany. Usually the supervisory board consists of a mixture of shareholder and labour representatives. If the Co-determination Act applies, the supervisory board must consist of one half shareholders and one half employee representatives. ${ }^{123}$ For this reason, founders and moving companies seek to avoid co-determination requirements. ${ }^{124}$ After the ECJ decisions it remains unclear whether restrictions of the freedom of establishment can be reconciled with the interests of employees. From a national point of view the question is: can a company that moves from one Member State to another be forced to comply with the co-determination regulations of the new home state? That would require some types of corporations to appoint employees' representatives to the board of directors. The German laws that govern co-determination expressly address German company forms such as the $G m b H$ and the $A G,{ }^{125}$ illustrating that the legislature did not anticipate the extension of German co-determination onto foreign company forms. Attempts to circumvent co-determination regulations might be unsuccessful, because some scholars support an analogy of German worker participation for pseudo-foreign companies. ${ }^{126}$ It is argued that this

119 See J J Du Plessis and Janet Dine "The Fate of the Draft Fifth Directive on Company Law: Accomodation Instead of Harmonisation" (1997) JBL 23, 24.

120 Davies above n 14, 112; David A Levy "Developments in Company Law" (1997) Online Journal of International Law and Development.

121 Du Plessis and Dine, above n 119, 32.

122 See for example AktG, 595.

123 German Co-determination Act 1976 (Mitbestimmungsgesetz [MitbG]) s 7, para 1.

124 Cheffins, above n 8, 433; Charny, above n 18, 454.

125 See MitbG, above n 123; German Works Council Constitution Act 1972 (Betriebsverfassungsgesetz [BetrVG]).

126 For example, Daniel Zimmer Internationales Gesellschaftsrecht - Das Kollisionsrecht der Gesellschaften und sein Verhältnis zum Internationalen Kapitalmarktrecht und zum Internationalen Unternehmensrecht 
regulatory gap was neither intended, nor foreseen, by the legislature, therefore German regulations could be applied to pseudo-foreign companies because that would govern only the same issue. ${ }^{127}$ It is questionable whether this analogy is consistent with the ECJ understanding of the freedom of establishment. Additionally, the topic of co-determination is highly controversial and scholars increasingly doubt its usefulness. ${ }^{128}$

An extension of co-determination faces not only legal but also practical problems. The German co-determination regulations as regards the $A G$ are bound to a two-tier board system, because the Aufsichtsrat (supervisory board) is where the participating employees act. ${ }^{129}$ This second nonexecutive board is not available in the Anglo-American corporate law system. What, for instance, if a company with a unitary board transfers its seat to a country where the two-tier structure is mandatory, and co-determination is organised within the supervisory board, and co-determination may be rendered applicable to this company, but not the rule mandating the two-tier system? The example of German co-determination rules highlights the problems from the ECJ judgments. Corporate law cannot be looked at in isolation; it is rather interlinked with several other legal areas, such as labour law. As long as European legislators are unable or reluctant to harmonise their laws generally, the consequences and difficulties that arise from the different corporate structures and various governance systems are far-reaching and partly unclear. Co-determination still seems possible, since the ECJ has stated that the protection of workers' rights might be, under certain circumstances, a justification for a curtailing of the freedom of establishment. ${ }^{130}$ In this case national legislators have to adjust their co-determination laws to further international scope. The current discussion about co-determination within the framework for the Societas Europaea, which will be discussed later, ${ }^{131}$ highlights how complicated this will be. However, it was possible to circumvent national co-determination regulations before the above-mentioned ECJ judgments, for instance by engaging a partnership or a "real" foreign company administrated abroad. ${ }^{132} \mathrm{Co}-$ determination also raises politically charged questions in relation to the self-understanding of workers and managers, and ethical questions over the fair sharing of power and control. There are

(Recht und Wirtschaft, Heidelberg, 1996) 292 [Internationales Gesellschaftsrecht]: Zimmer changed his opinion after Inspire Art, considering the legal consequences of an analogous co-determination would be inappropriate for company forms with other corporate structures: see Zimmer, above n 60, 3590.

127 Internationales Gesellschaftsrecht, above n 126.

128 Kersting and Schindler, above n 101, 624; Peter Ulmer "Paritätische Arbeitnehmermitbestimmung im Aufsichtsrat von Grossunternehmen" (2002) ZHR 271.

129 Steven M Bainbridge "Participatory Management Within the Theory of the Firm" (1996) 21 Iowa J Comp L 657,689 fn 180, 181

130 For example Überseering, above n 30, para 92.

131 See Part VII The European Company.

132 Zimmer, above n 60, 3590. 
already legal advisers that say business can now be done in Germany without having to adhere to German co-determination rules at the supervisory board level, simply by selecting a non-German company form. ${ }^{133}$ Since the ECJ judgments do not guarantee a freedom to move out, companies established under legal regimes providing for co-determination cannot easily escape these regulations. ${ }^{134}$ Thus, the co-determination rules remain a stumbling block for European corporate law harmonisation and the free movement of companies within Europe.

\section{Creditor Protection}

Even before the ECJ judgments, the voices questioning whether minimum capital is an adequate measure of creditor protection were getting louder. ${ }^{135}$ The only existing European minimum capital requirements apply to public limited companies and the Societas Europaea. ${ }^{136}$ In some Member States there is a huge effort to make sure a private limited company has a certain amount of capital when it starts business, otherwise its executives are personally liable. But whether the minimum capital is EUR 3000 as it is in Spain, or EUR 35,000 as it is in Austria, neither guarantees a company's survival if the management or the market conditions turn out to be bad. Kindler, for example argues that the shift of the risk of insolvency in the case of undercapitalised foreign companies from shareholders to creditors is not part of the scope of protection of the freedom of establishment and for this reason cannot be decided by the ECJ cases. ${ }^{137}$ Technically he is right; the ECJ did not decide that a shift of the risk is necessary under the freedom of establishment. It decided solely that it is inconsistent with the freedom of establishment to impose domestic minimum capital requirements on companies that incorporate or reincorporate in another Member State. Accordingly, the criticised shift of risk is just a practical consequence and not a sentence, since founders and managers are now allowed to choose the company law they prefer.

It is no longer possible to use the real seat doctrine to protect national markets from companies established under company law of other Member States, ${ }^{138}$ but, as the Danish minimum capital requirement under tax law shows, Member States have already started to look for alternative ways to regulate pseudo-foreign companies.

133 Jones Day Commentaries "Recent Legal Developments in the European Union Regarding Cross-Border Transactions" (April 2004) 2.

134 Zimmer, above n 60, 3590.

135 Friedrich Kübler Aktie, Unternehmensfinanzierung und Kapitalmarkt (Carl Heymanns, Cologne, 1989) 59; "Die deutsche GmbH - ein Modell von gestern?" (January 2004) Advoselect News Stuttgart 4.

136 Second Council Directive (EEC) 77/91, above n 88, requires EUR 25,000 for public limited companies within Europe, art 4, para 2 of the SC Regulation requires a subscribed capital of EUR 120,000.

137 Kindler, above n 58, 1078.

138 Nikolaus Adensamer and Cecile Bervoets Nationaler Gläubigerschutz auf dem Prüfstand (2003) 11 RdW 617,620 . 


\section{THE EUROPEAN COMPANY}

The European Commission has been trying unsuccessfully for almost 35 years to implement an inter-European company. The Societas Europaea (SE), first proposed in 1970, finally became available on 8 October 2004. ${ }^{139}$ In absence of the Tenth and Fourteenth Directives, ${ }^{140}$ it is the first vehicle allowing companies to merge if they are established under, and governed by, the laws of different Member States. ${ }^{141}$ Due to the reluctance of Member States' governments to give up their national corporate laws, the $S E$ Regulation only sets out a general framework for the $S E$.

According to article 7 of the Regulation for a European Company, the company's seat and the administrative centre have to be in the same Member State to ensure effective monitoring of the company by that Member State. This also applies to states that apply the foundation theory. Unlike under the real seat theory, the location of the company's seat and administrative centre would not affect the legal capacity of the company; nevertheless, it would cause an illegal situation under the $S E$ Regulation for a company to have its registered seat and its administrative centre in different Member States. If a company does not comply with article 7, the final consequence will be the winding-up of the company. ${ }^{142}$

The regulation is a compromise between the foundation and the real seat theory, since the registered office cannot be moved unless the head office or central administration is also moved. This solution has somewhat limited the flexibility of the $S E$ and seems to conflict with the ECJ's broad understanding of the freedom of establishment, because this regulation burdens companies in a way that hampers their freedom to move. At the moment this regulation must be accepted, but it remains to be seen whether it will be revised. At least in 2009 the current article 7 should be replaced by a more liberal regulation. ${ }^{143}$

139 Council Regulation (EC) 2157/2001 on the statute for a European company (2001).

140 Proposal for a Tenth Council Directive based on Article 54 (3) (G) concerning cross-border mergers of public limited companies COM/84/727FINAL (25 January 1985), withdrawn in December 2001, and Proposal for a Directive of the European Parliament and of the Council on cross-border mergers of companies with share capital COM(2003)703FINAL (18 November 2003);

Proposal for a Fourteenth European Parliament and Council Directive on the transfer of the registered office of a company from one member state to another with change of applicable law XV/D2/6002/97-EN REV 2 (1997).

141 Jones Day Commentaries, above n 133, 1; Davies, above n 14, 24.

142 Council Regulation (EC) 2157/2001, above n 139, art 64(2); see Clemens P Schindler "'Überseering' und Societas Europaea: Vereinbar oder nicht vereinbar, das ist hier die Frage" (2003) RdW 122, 123.

143 Council Regulation 2157/2001/EC, above n 139, art 69a requires the Commission to review until 8 October 2009 , among other things, whether it is advisable to allow seat and administrative centre to be located in different Member States. 
Article 8 states that a company must prove it will adequately protect the interests of creditors and other rights-holders before it can relocate its seat. ${ }^{144}$ However, the Regulation does not define what "adequate" protection means, so this requirement will cause new speculation and uncertainty. Will all creditors and holders of other rights demand a choice of forum agreement to avoid suing abroad? In this case the relocation of the company seat will still be a complex and time-consuming process, requiring a lot of legal advice.

Due to different degrees and systems of workers' participation in Member States, ranging from informing employees after decisions have been made to participation in the decision-making itself, and the inability to reach a consensus in this area, the way to implement co-determination is left open, which will lead to a further diversity of $S E \mathbf{s} .{ }^{145}$ According to the Directive supplementing the Statute for a European Company with regard to the involvement of employees, ${ }^{146}$ a body of employee representatives from the companies involved in the transaction must negotiate about the future rights of the employees in the $S E$ with the management of the companies subject to the transaction. ${ }^{147}$ The $S E$ Directive contains highly complex rules on how the employees approve the agreement reached in such negotiations. Several participation models are possible: firstly, a model where employees form part of the supervisory board or the administrative board; secondly, a model where employees are represented by a separate body; and finally, other models to be agreed upon between the management or supervisory boards of the founder companies and the employees or their representatives in those companies, the level of information and consultation being the same as in the case of the second model. If negotiations fail to achieve an agreement, a European works council must be established, which has certain information and consultation rights. The general meeting may not approve the formation of an $S E$ unless one of the several models of participation defined in the Directive has been chosen.

Furthermore, an intricate set of rules determines in which instances employees retain their rights to be represented via works councils or board representatives they had prior to the transaction establishing the $S E$.

The rules on the employees' rights in an $S E$ require a costly and time-consuming procedure. ${ }^{148}$ They can also bring about some surprising results. For example, depending on where the employees are located, an $S E$ with its headquarters in Ireland, thus subject in part to Irish corporate laws, may

144 Schindler, above n 142, 124.

145 Davies, above n 14, 67; Maria C Cauchi "The Concept of Employee Participation under the Proposed Societas Europaea" available at $<$ http://www.cc-advocates.com> (last access 22 July 2005).

146 Council Directive (EC) 2001/86 supplementing the Statute for a European Company with regard to the involvement of employees [2001] OJ L294.

147 Council Directive (EC) 2001/86, above n 146, art 3(1).

148 According to Council Directive (EC) 2001/86, above n 146, art 5(2) negotiations can last up to one year. 
fall within the scope of the German co-determination rules. Such rules, on the other hand, do not necessarily apply to an $S E$ located in Germany if most of its employees work outside of Germany. The formation of an $S E$ may thus be less attractive for companies likely to be subject to extensive employees' rights.

All of this leads some lawyers to conculde that establishing an $S E$ is too cumbersome and timeconsuming to become general practice. ${ }^{149}$ Another major criticism is that the $S E$ has been designed for large enterprises. Arguably, a specific European Company should not be reserved for big businesses only when most businesses are small and medium sized enterprises (SMEs). There is arguably a specific need for a European structure to flexibly establish cross-border joint ventures for SMEs.

As a consequence of different board structures and various co-determination rules, there will not be a uniform $S E$, but a variety of $S E \mathrm{~s}$, still depending on the corporate and other laws of the Member States where the $S E$ s have their registered office. What was initially planned as a supra-national company form, independent of the national laws of the Member States, will ultimately be available in a diluted form, partly governed by European and partly by domestic law. The $S E$ fails not only to regulate core company law issues but also important related areas such as taxation or insolvency. ${ }^{150}$ Due to Member States' unwillingness to forfeit national legislative sovereignty and traditional opinions concerning corporate structure and labour participation, the $S E$ is not a single European company but rather a construction kit with various options to choose from. Although it has taken national negotiators much work to reach this little consensus, the importance of the final version of the $S E$ will be mostly symbolic. Since the ECJ has interpreted the freedom of establishment for companies broadly, judicial reality has already overtaken legislation. One major benefit of the $S E-$ the possibility to move across borders - has been achieved in advance by the ECJ for all companies. To make the $S E$ attractive now, regulations concerning relocation of the seat and the centre of administration of the $S E$ should be brought in line of the approach taken by the ECJ.

\section{CONCLUSION}

Company law in the EU has traditionally been the domain of national courts but this is no longer the case. The ECJ has made clear in several decisions that the freedom of establishment includes recognition of limited liability, legal capacity and standing of companies established in another Member State. There are possible exceptions to this general rule, but it is unclear what a justifiable exception might be in practice. The consequences of these rulings for the internal market are remarkable, but not as significant as it might seem at first. Since the ECJ based its judgments solely on the freedom of establishment provided by the EC Treaty, it did not deal with substantial company law. Consequently, there are a lot of unanswered questions in the aftermath of the judgments.

149 Jones Day Commentaries, above n 133, 4.

150 Davies, above n 14, 25. 
However, in contrast to national and European legislation, which have been dealing with this problem for decades, the ECJ has made progress regarding the free movement of companies.

It has become apparent that some of the differences between company law systems of Member States, particularly those concerning the transfer of the company seat, constitute a significant burden on the mobility of companies within the EU and therefore impair their competitiveness on an international level. To achieve a greater competitiveness of European companies, regulations must become more practicable. In Europe there is a strong tendency towards the coexistence of different regimes, since national governments are reluctant to forfeit sovereignty to superior European law. The question to be asked is whether coexistence is sufficient for the future challenges that will occur within and beyond Europe? Since May 2004 the EU has ten new Member States, and with them ten new company law regimes. The more Member States the EU has, the greater is the need for harmonisation to enable companies to move within the region. On the other hand, the more negotiators are involved in the harmonisation process, the harder it is to find a consensus. Issues like co-determination highlight that there is a lot more to do to disentangle national features from corporate law and the ability to do business easily across Europe.

As a result of the ECJ decisions, the pressure on national legislators in the EU Member States has increased to make their corporate laws more attractive to investors. To become or remain competitive it may now be necessary to abolish some traditional and bureaucratic hindrances for business, even if these regulations are well established in the domestic legal system. Overregulated corporate laws, such as the German system, run the risk of losing importance within the EU. The ECJ judgments have opened the door for healthy national and community-wide discussions, not only about corporate law, but also about related areas such as creditor protection and codetermination. This is an opportunity for streamlining and enhancing legal systems among the Member States. As Hopt observes: "Company law must concern itself with reality, not just with concepts and dogmas."151

151 Hopt, above n 3, 12. 
